\title{
EVALUATION OF RESULTS OF ROAD RESEARCH OF LANOS CAR, EQUIPPED WITH AN ADVANCED HYDRAULIC BRAKE DRIVE
}

\author{
I. Nazarov, P.G., \\ Kharkov National Automobile and Highway University
}

\begin{abstract}
The results of studies of road emergency braking of the car, the brake system equipped with an improved hydraulic brake actuator according to the patent number 76189 Ukraine are analyzed. This drive provides more efficient emergency braking of cars under operating conditions by of installing in each of the contours of the rear brakes one brake-power, each of which provides distribution of braking forces between the wheels of the corresponding side.
\end{abstract}

Key words: passenger car, hydraulic brake actuator, on-board braking force, emergency braking, brake force, airborne brake force distribution, traffic studies.

\section{ОЦЕНКА РЕЗУЛЬТАТОВ ДОРОЖНЫХ ИССЛЕДОВАНИЙ ЛЕГКОВОГО АВТОМОБИЛЯ LANOS, ОБОРУДОВАННОГО УСОВЕРШЕНСТВОВАННЫМ ГИДРАВЛИЧЕСКИМ ТОРМОЗНЫМ ПРИВОДОМ}

\author{
И.А. Назаров, асп., \\ Харьковский национальный автомобильно-дорожный университет
}

Аннотация. Анализируются результаты дорожных исследований экстренных торможений легкового автомобиля, тормозная система которого оборудована усовершенствованным гидравлическим тормозным приводом по патенту № 76189 Украины.

Ключевые слова: легковой автомобиль, гидравлический тормозной привод, бортовая тормозная сила, экстренное торможение, дорожные исследования.

\section{ОЦІНКА РЕЗУЛЬТАТІВ ДОРОЖНІХ ДОСЛІДЖЕНЬ ЛЕГКОВОГО АВТОМОБІЛЯ LANOS, ОБЛАДНАНОГО ВДОСКОНАЛЕНИМ ГІДРАВЛІЧНИМ ГАЛЬМІВНИМ ПРИВОДОМ}

\author{
I.O. Назаров, асп., \\ Харківський національний автомобільно-дорожній університет
}

Анотація. Аналізуються результати дорожніх досліджень екстрених гальмувань легкового автомобіля, гальмівна система якого обладнана вдосконаленим гідравлічним гальмівним приводом за патентом № 76189 України.

Ключові слова: легковий автомобіль, гідравлічний гальмівний привід, бортова гальмівна сила, екстрене гальмування, дорожні дослідження.

\section{Introduction}

The estimated figures of brake efficiency of operated motor cars is the value of steady maximum deceleration and the value of the minimum stopping distance, traveled by the car from the beginning of braking with the required speed up to its full stop.
Both evaluation indexes are linked. Therefore, in US only one of them is normalized - the minimum stopping distance.

It is considered that the steady deceleration is independent of the initial braking speed, which creates certain advantages when used; however, the braking distance characterizes the traffic safety. 
There are established different standards for assessing the performance of brake systems of passenger cars, which are regulated by a number of both international and national standards [1-3].

\section{Analysis of publication}

Road tests of motor cars, carried out according to the known standards, are to determine their inhibitory properties, i.e. the value of the steady deceleration and braking distance under certain road conditions [1-3].

The requirements of different standards establish the value of implemented deceleration of the car in running order at least $7 \mathrm{~m} / \mathrm{c}^{2}$ and the limit braking distance at a certain initial braking speed on level ground with a dry asphalt surface.

Thus, at the initial braking speed of $40 \mathrm{~km} / \mathrm{h}$ the braking distance of the car in the running order shall not exceed $17,4 \mathrm{~m}$ and at $80 \mathrm{~km} / \mathrm{h}$, the stopping distance should not exceed 43,2 m. These values are listed in the present Highway Code of Ukraine. In this case, the action of the aerodynamic resistance of the vehicle movement is neglected, stipulating the wind speed to be $0,3-0,5 \mathrm{~m} / \mathrm{s}$, at which the tests are conducted $[1,3]$.

For the same reason in the classical literature $[4,5]$ there are given the dependencies to determine the limiting deceleration values and the braking distance of the vehicle, ignoring the force of air resistance.

However, as shown by theoretical studies [6-9] the longitudinal component of the aerodynamic drag force acting on the vehicle during braking has an impact on the redistribution of normal axial reactions.

With that, in case of vehicle braking on level roads they are homogeneously distributed between the wheels of similar axes.

A completely different situation occurs during braking of vehicles in the event of total aerodynamic force components action not only on a flat road, but on a level road with a transverse slope, with a fixed radius of curvature and on the roads with a longitudinal slope, i.e. under operating conditions [10-13].

Such a law [14] of axial normal reactions distribution, and thus the braking forces between the axles must be satisfied by the vehicle braking drive action.

However, the modern methods of braking force distribution between the axles of passenger cars [15] and the design of brake actuators, providing it, fail to effectively implement the change of normal reactions in operating conditions not only between the axles, but also between the wheels of various vehicles.

One of the options for improving the braking drive of cars is the designed brake actuator [16], which implements the method [17] of brake force distribution between the wheels of its various sides.

\section{Purpose and problem statement}

The purpose of road tests lies in establishment of the minimum amount of change in the steady deceleration and braking way of the Lanos motor car standard configuration, equipped with an improved hydraulic brake actuator, on a level road.

The object of road tests is to estimate the effect of the aerodynamic factor on the inhibitory properties of the Lanos motor car.

Subject of research - the process of emergency braking of Lanos motor car.

\section{The methodology of carrying out road tests}

Lanos car tests of basic configuration were held in a state of partial $(1220 \mathrm{~kg})$ and full load $(1595 \mathrm{~kg})$. At this, there was allowed the presence of instrumentation and the load balancer, evenly placed in the passenger compartment and the trunk of the car in accordance with the requirements [1-3].

A series of emergency braking of the car in a different weight state was produced in calm weather on a road site with dry asphalt concrete pavement (without longitudinal and transverse slope) of Zaporozhe Auto Plant.

Initial braking speed varied from 40 to $150 \mathrm{~km} / \mathrm{h}$. The wind speed at the indication of the anemometer was $0,3-0,5 \mathrm{~m} / \mathrm{s}$.

Before carrying out the road test the braking system of the Lanos motor car, equipped with an improved hydraulic brake actuator [16], one of 
the circuits of which is shown in Fig. 1, was tested for compliance with requirements [1-3].

To register the value of deceleration and the stopping distance of the Lanos motor car there was used the equipment of the design and operational department of Zaporozhe Automobile Building Plant ZAZ: a decelerometer with an integrated Maha VZM 300 printer, a cup anemometer MS-13 GOST 6376-74.

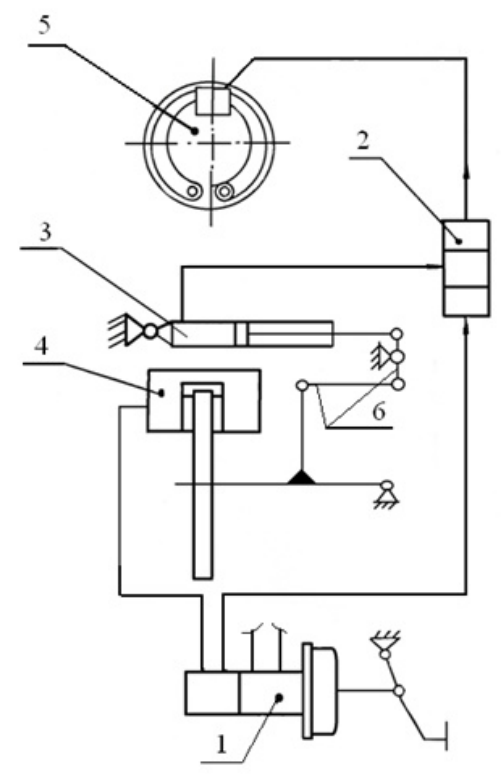

Fig. 1. Equipment of the car with an advanced brake actuator [16]: 1 - master brake cylinder assembly; 2 - controlled brake force governor; 3 -pilot cylinder assembly; 4 front axle brake actuator; 5 - rear axle brake actuator; 6 - articulation-linkage assembly

Table 1 Results of road studies of the Lanos car equipped with an advanced brake actuator (Record №044.BSI 2016)

\begin{tabular}{|c|c|c|c|c|c|c|c|c|}
\hline \multirow{3}{*}{ Experiment } & \multicolumn{4}{|c|}{ Kerb weight } & \multicolumn{4}{|c|}{ Complete load } \\
\hline & \multicolumn{8}{|c|}{ Initial braking speed, $\mathrm{km} / \mathrm{h}$} \\
\hline & 80 & 100 & 130 & 150 & 80 & 100 & 130 & 150 \\
\hline \multirow{2}{*}{ №1 } & 7,18 & 7,35 & 7,56 & 7,64 & 7,03 & 7,22 & 7,44 & 7,62 \\
\hline & 31,80 & 42,90 & 73,48 & 100,6 & 37,58 & 45,90 & 76,27 & 101,8 \\
\hline \multirow{2}{*}{ №2 } & 7,17 & 7,33 & 7,55 & 7,62 & 7,02 & 7,20 & 7,42 & 7,61 \\
\hline & 31,92 & 43,04 & 73,72 & 100,92 & 37,70 & 46,05 & 76,51 & 102,1 \\
\hline \multirow{2}{*}{ №3 } & 7,15 & 7,32 & 7,53 & 7,61 & 7,01 & 7,19 & 7,41 & 7,59 \\
\hline & 31,93 & 43,08 & 73,66 & 100,85 & 37,73 & 46,09 & 76,58 & 102,2 \\
\hline \multirow{2}{*}{ №4 } & 7,19 & 7,37 & 7,58 & 7,66 & 7,05 & 7,24 & 7,46 & 7,64 \\
\hline & 31,75 & 42,83 & 73,36 & 100,43 & 37,52 & 45,82 & 76,14 & 101,6 \\
\hline \multirow{2}{*}{ №5 } & 7,21 & 7,38 & 7,59 & 7,67 & 7,06 & 7,25 & 7,47 & 7,65 \\
\hline & 31,64 & 42,69 & 73,12 & 100,11 & 37,39 & 45,68 & 75,90 & 101,3 \\
\hline
\end{tabular}

Note. In the top line there is indicated the deceleration $\mathrm{m} / \mathrm{s}^{2}$, in the bottom line - the braking distance, $\mathrm{m}$.
In the process of testing, the motor car accelerated to the speed exceeding the initial braking speed of $3-5 \mathrm{~km} / \mathrm{h}$. Then the clutch was disengaged and, when the magnitude of the initial braking speed was reached, the brakes were engaged and the vehicle stopped.

After the braking process was over, there were registered the displayed measured values of both deceleration and the braking distance.

The average value of 2 measurements in the forward and backward direction was considered

As part of the above road research program five experiments were conducted.

\section{Analysis of road test results}

Comparative evaluation of the results of road tests of the Lanos motor car was performed, using the results of theoretical research and the results of road tests of the Lanos motor car equipped with a modern brake actuator (according to the manufacturer's testing protocol №058.BSI 2010).

Since at the initial deceleration speed of less than $80 \mathrm{~km} / \mathrm{h}$ the values of fixed parameters of Lanos vehicles, equipped with an existing and advanced brake actuator, revealed the least difference (up to $6 \%$ ), then the latter in Table 1 and Table 2 are conditionally not shown. to be the result of measurements conducted. 
Table 2 The theoretical values of braking parameters of Lanos cars

\begin{tabular}{|c|c|c|c|c|c|c|c|c|}
\hline \multirow{4}{*}{ Vehicle weight } & \multicolumn{8}{|c|}{ Values of deceleration parameters of Lanos car } \\
\hline & \multicolumn{4}{|c|}{$\begin{array}{l}\text { According to classic dependencies } \\
\text { (1) and (2) }\end{array}$} & \multicolumn{4}{|c|}{$\begin{array}{l}\text { According to obtained dependences } \\
\text { (3) and (4) }\end{array}$} \\
\hline & \multicolumn{8}{|c|}{ At the initial braking speed, $\mathrm{km} / \mathrm{h}$} \\
\hline & 80 & 100 & 130 & 150 & 80 & 100 & 130 & 150 \\
\hline \multirow{2}{*}{1220 кг } & \multicolumn{4}{|c|}{7,85} & 8,19 & 8,38 & 8,88 & 9,02 \\
\hline & 31,46 & 49,16 & 83,08 & 110,6 & 30,91 & 47,57 & 78,55 & 97,5 \\
\hline \multirow{2}{*}{1595 кг } & \multicolumn{4}{|c|}{6,85} & 8,06 & 8,18 & 8,49 & 9,13 \\
\hline & 35,46 & 56,18 & 94,75 & 116,6 & 36,14 & 48,11 & 80,10 & 99,5 \\
\hline
\end{tabular}

Note. In the top line there is indicated deceleration, $\mathrm{m} / \mathrm{s}^{2}$, in the bottom line - the braking distance, $\mathrm{m}$.

Analysis of outcomes of road (Table. 1) and theoretical (Table. 2) investigations show that with the growth of the initial braking speed for Lanos cars equipped with an advanced hydraulic brake actuator [16] there are implemented large deceleration and the corresponding lower values of braking distances for both weighting states.

The results of road tests were determined according to [18].

Thus, the value of the average steady deceleration for Lanos passenger cars, braking on dry asphalt concrete at the initial speed that varies from $80 \mathrm{~km} / \mathrm{h}$ to $150 \mathrm{~km} / \mathrm{h}$ constitutes (Table 1 ):

- curb weight $7,18-7,64 \mathrm{~m} / \mathrm{s}^{2}$;

- with full load 7,03-7,62 m/s $\mathrm{s}^{2}$.

Whereby, with an increase of the initial velocity of deceleration the value of the average Lanos vehicle braking path is:

- Curb weight 31,81-100,58 m;

- Complete load 37,58-101,8 m.

As a result of theoretical studies (Table 2) there were determined the values of deceleration and braking distances obtained for the Lanos car:

- by classical dependencies [4, 5] (with an existing brake actuator)

$$
\begin{gathered}
j_{T}=\frac{P_{\mathrm{T} 1}+P_{\mathrm{T} 2}}{m_{\mathrm{a}}} \leq \varphi \cdot g, \\
s_{T}=\frac{\vartheta_{0}{ }^{2}}{2 \cdot[j]},
\end{gathered}
$$

where $\varphi$ - coefficient of adhesion; $P_{\mathrm{T} 1}, P_{\mathrm{T} 2}-$ the braking force applied to the front and rear axle, respectively; $m_{\mathrm{a}}$ - weight of the vehicle; $\vartheta_{0}$ - the initial vehicle deceleration speed;

- According to the obtained dependencies [19] (with an improved brake actuator)

$$
\begin{array}{r}
j_{T}=z \cdot g+\left(K_{0} \cdot F_{w} \cdot{ }_{0}^{2}\right) / m_{a} \cdot\left(1-\lambda_{z} \varphi\right) ; \\
S_{\mathrm{T}}=\frac{m_{\mathrm{a}}+\sum \frac{J_{i}}{r_{k}^{2}}}{2 K_{\mathrm{o}} \cdot F_{w}} \cdot \ln \left(1+\frac{K_{\mathrm{o}} \cdot F_{w} \cdot \vartheta_{0}^{2}}{m_{\mathrm{a}} \cdot g \cdot \varphi}\right),
\end{array}
$$

where $z$-drag coefficient; $K_{0}=0,35 \mathrm{~kg} / \mathrm{m}^{3}-$ streamlining factor of the Lanos car body; $F_{w}$ frontal drag area of the vehicle; $\lambda_{z}=0,1-$ share of the lifting component in the drag force; $J_{i}-$ moment of inertia of rotating masses; $r_{k}-$ rolling radius of the wheel.

As the analysis of calculated values of braking parameters of the Lanos vehicle equipped with an improved hydraulic brake actuator shows (Table. 2) when the initial braking velocity changes within $80-150 \mathrm{~km} / \mathrm{hour}$, the theoretical value of steady deceleration is:

- curb weight 8,19-9,02 m/2

- complete load 8,06-9,13 m/s $\mathrm{s}^{2}$.

At the same time the estimated value of the braking distance of the Lanos car is:

- curb weight 30,91-97,5 m;

- complete load 36,14-99,5 m.

Comparative analysis of both the theoretical (Table 2) and experimental (Table 1) values of the emergency braking parameters of the Lanos car shows that their relative difference is: 
- when assessing the magnitude of deceleration:

a) curb weight $12,3-15,3 \%$;

б) complete load $12,7-16,5 \%$.

- when assessing the value of the braking distance:

a) curb weight $2,8-3,1 \%$;

б) complete load $2,3-3,8 \%$.

Relatively lesser values of deceleration magnitudes at emergency braking of the Lanos car, obtained during experimental studies, take place in connection with a decrease in the coefficient of wheels friction with the road surface [10], which is caused by an increase in the initial braking speed and the normal load on the wheels of the rear axle.

However, this issue requires further research.

Comparative analysis of theoretical braking parameters (Table. 2) of the Lanos car, equipped with an improved and existing hydraulic brake actuator, shows that under emergency braking on a dry asphalt road covered with an increase of the initial braking speed of $80-150 \mathrm{~km} / \mathrm{h}$ :

- at curb weight the steady deceleration is increased by $15 \%$, while the braking distance is reduced by $12 \%$;
- at the complete weight the steady deceleration increases by $24 \%$, thus the limiting stopping distance is reduced by $16 \%$.

Consequently, despite the change in the coefficient of friction during emergency braking, consideration of the effect of aerodynamic resistance of the vehicle leads to improved braking characteristics.

Based on the results of road tests of Lanos cars equipped with an existing hydraulic brake actuator (Table. 3), it can be stated that vehicles with a basic configuration (without ABS) at partial loading on a dry asphalt road surface at the initial speed of $100 \mathrm{~km} / \mathrm{h}$, according to the factory test data, have a braking distance of $48,2 \mathrm{~m}$ with a steady deceleration of $6,2 \mathrm{~m} / \mathrm{s}^{2}$

At the same time according to the road test conducted (Table 3) for the same vehicle, equipped with an improved hydraulic brake actuator, the maximum braking distance is 42,9 meters, which is $11 \%$ less than for Lanos cars with a basic configuration at steady deceleration of $7,35 \mathrm{~m} / \mathrm{s}^{2}$.

Table 3 The values of braking parameters obtained during road tests of Lanos car

\begin{tabular}{|c|c|c|c|c|c|c|c|c|}
\hline \multirow{4}{*}{ Vehicle weight } & \multicolumn{8}{|c|}{ Values of braking parameters of Lanos car } \\
\hline & \multicolumn{4}{|c|}{$\begin{array}{l}\text { with an existing brake actuator } \\
\text { (report №058.BSI-2010) }\end{array}$} & \multicolumn{4}{|c|}{$\begin{array}{l}\text { with an improved brake actuator } \\
\text { (report №044.BSI-2012) }\end{array}$} \\
\hline & \multicolumn{8}{|c|}{ при начальной скорости торможения, км/ч } \\
\hline & 40 & 60 & 80 & 100 & 80 & 100 & 130 & 150 \\
\hline \multirow{2}{*}{ curb weight } & 4,7 & 5,8 & 6,8 & 6,2 & 7,18 & 7,35 & 7,56 & 7,64 \\
\hline & 13,1 & 24,3 & 39,6 & 48,2 & 31,8 & 42,9 & 73,48 & 100,6 \\
\hline
\end{tabular}

Note. In the top line there is indicated deceleration in $\mathrm{m} / \mathrm{s}^{2}$, in the bottom line - the braking distance, $\mathrm{m}$.

As a result, the above-said theoretically and practically confirms the opportunity to improve the efficiency of potential passenger cars with any degree of loading and under any operating conditions equipped with an improved hydraulic brake actuator [16], which allows implementing the specific vehicle braking force more fully.

\section{Conclusions}

Based on comparative analysis of road studies and theoretical data, it was revealed that at initial braking speed up to $80 \mathrm{~km} / \mathrm{h}$ the values of limit braking distance of Lanos cars differ insignificantly (up $6 \%$ ). This is due to the fact that in case of emergency braking of passenger cars with the streamlining car body factor of $K_{o}=0,35 \mathrm{~kg} / \mathrm{m}^{3}$, at braking speed below $80 \mathrm{~km} / \mathrm{h}$ the strength of the aerodynamic air flow resistance does not have a noticeable effect.

Comparative analysis of theoretical parameters of emergency braking shows that the considered passenger vehicles equipped with an advanced hydraulic brake actuator, when performing emergency braking on dry asphalt concrete with an initial speed varying from 80 to $150 \mathrm{~km} / \mathrm{h}$ :

a) at partial loading steady deceleration increases by $15 \%$, thus the limiting stopping distance is reduced by $12 \%$; 
b) at complete load steady deceleration increases to $24 \%$ and the limiting stopping distance is reduced by $16 \%$.

According to the road research the limiting stopping distance for the Lanos car, equipped with an improved hydraulic brake actuator, with partial load at the initial braking speed of $100 \mathrm{~km} / \mathrm{h}$ is $42,9 \mathrm{~m}$, which is $11 \%$ less than for the Lanos car of basic version.

At the same time the implemented minimum deceleration speed is $7,35 \mathrm{~m} / \mathrm{s}^{2}$, which meets the requirements of the national standard regulating the value of implemented deceleration no less than $7 \mathrm{~m} / \mathrm{s}^{2}$.

The results of theoretical and experimental studies confirm the potential opportunity for increasing the efficiency of cars with any degree of loading by advanced hydraulic brake actuator equipment [16], which allows implementing the specific vehicle braking force in all operating conditions more fully.

\section{References}

1. Тормозные свойства автотранспортных средств. Методы испытаний: ОСТ 37.001.067-86. - Офиц. изд. - [Введен 1988-01-01]. - М.: Минавтопром СССР, 1988. -64 c.

2. Тормозные свойства автотранспортных средств. Нормативы эффективности. Технические требования: ГОСТ 2289577. - Офиц. изд. - [Введен с 1981-01-01]. - М.: Изд-во стандартов, 1981. - 19 с.

3. Колісні транспортні засоби. Вимоги щодо безпечності технічного стану та методи контролювання (Б3 №11-12-2010/436): ДСТУ 3649: 2010. - Офіц. вид. - [Чинний від 28.11.2010]. - К.: Держспоживстандарт України, 2011. - 26 с. - (Національний стандарт України).

4. Булгаков Н.А. Исследование динамики торможения автомобиля. Научное сообщение №18 / Н.А. Булгаков, А.Б. Гредескул, С.И. Ломака. - Харьков: Изд-во госуниверситета им. А.М. Горького, 1962. - 36 c.

5. Ломака С.И. Автоматизация процесса торможения автомобиля: учеб. пособ. для студ. высш. учеб. завед. / С.И. Ломака, Н.Н. Алекса, Е.М. Гецович. - К.: УМК BO, 1988. -88 c.
6. Гухо В.Г. Аэродинамика автомобиля / В.Г. Гухо. - М.: Машиностроение, 1987. $-403 \mathrm{c}$.

7. Исследование потенциальных возможностей автомобиля при действии боковой силы в процессе торможения / А.С. Федосов, М.А. Подригало // Автомобильный транспорт. - 1980. -Вып. 17. - C. 73-78.

8. Стабильность эксплуатационных свойств колесных машин / Подригало М.А., Волков В.П., Карпенко В.А. и др.; под ред. М.А. Подригало. - Х.: ХНАДУ, 2003. $614 \mathrm{c}$.

9. Реализация интеллектуальных функций в электронно-пневматическом управлении транспортних средств: монография / А.Н. Туренко, В.И. Клименко, Л.А. Рыжих и др. - Х.: ХНАДУ, 2015. - 450 с.

10. Назаров В.И. Перераспределение вертикальных нагрузок при экстренном торможении легкового автомобиля, движущегося в воздушном потоке на горизонтальном участке дороги / В.И. Назаров // Вісник НТУ «ХПІ». - 2014. - №1. - C. 102-110.

11. Исследование потенциальных возможностей автомобиля при действии боковой силы в процессе торможения / А.С. Федосов, М.А. Подригало // Автомобильный транспорт. - 1980. - Вып.17. C. 73-78.

12. Русановский А.Е. Влияние эксплуатационных факторов на тормозную динамику автомобиля, оборудованного регуляторами тормозных сил: автореф. дис. на соискание ученой степени канд. техн. наук: спец. 05.22.20 «Эксплуатация и ремонт средств транспорта»/ А.Е. Русановский. - Волгоград, 1982. - 18 с.

13. Подригало М.А. Анализ неравномерности вертикальных реакций на колесах и ее влияние на эксплуатационные свойства автомобиля / М.А. Подригало // Автомобильный транспорт: проблемы и перспективы: материалы IV Междунар. научно-техн. конф., 11-15 апр. 2000 г. Севастополь: СевГТУ, 2000. - С. 76-79.

14. Гредескул А.Б. Законы регулирования тормозных сил автомобиля при действии боковой силы в процессе торможения / А.Б. Гредескул, М.А. Подригало, Н.Ю. Фаворов. - Х.: ХАДИ, 1980. $24 \mathrm{c}$.

15. Маневренность и тормозные свойства колесных машин / М.А. Подригало, 
В.П. Волков, В.И. Кирчатый, А.А. Бобошко; под ред. М.А. Подригало. - Х.: ХНАДУ, 2003. - $403 \mathrm{c}$.

16. Пат. №76189 Україна, МПК 2006.01, В60Т 8/24. Пристрій для підвищення ефективності гальмування легкових автомобілів / [Подригало М.А., Назаров B.I., Назаров О.I., Назаров I.О.]; заявник i патентовласник Харківський національний автомобільно-дорожній університет. - №u201207284; заявл. 15.06.2012; опубл. 25.12. 2012, Бюл. №24.

17. Пат. №75406 Україна, МПК 2012.01, В60T 11/00. Спосіб регулювання гальмівних сил між осями легкового автомобіля / Подригало М.А., Назаров В.I., Назаров О.І., Назаров I.О.; заявник і патентовласник Харківський національний автомобільно-дорожній університет. №u201207282; заявл. 15.06.2012; опубл. 26.11. 2012, Бюл. №22.

18. Романов В.Н. Теория измерений. Анализ и обработка экспериментальных данных: учебное пособие / В.Н. Романов, В.В. Комаров. - С.Пб.: СЗТУ, 2002. $127 \mathrm{c}$.

19. Назаров И.А. Повышение тормозных свойств легковых автомобилей, оборудованных гидравлическим тормозным приводом, обеспечивающим бортовое распределение тормозной силы / И.А. Назаров, В.И. Назаров, А.И. Назаров // Альтернативные источники энергии в транспортно-технологическом комплексе: сб. науч. тр. - 2016. Вып. 1(4), Т.3. - С. 342-347.

\section{References}

1. OST 37.001.067-86. Tormoznyie svoystva avtotransportnyih sredstv. Metodyi ispyitaniy [Industry Standard 37.001.06786. Brake properties of vehicles. Methods of tests]. Moscow, Minavtoprom SSSR Publ., 1988. $64 \mathrm{p}$.

2. GOST 22895-77. Tormoznyie svoystva avtotransportnyih sredstv. Normativyi effektivnosti. Tehnicheskie trebovaniya [State Standard 22895-77. Brake properties of vehicles. Norms of efficiency. Technical requirements]. Moscow, Standartinform Publ., 1981. 18 p.

3. DSTU 3649: 2010. Kolisni transportni zasoby. Vymohy shchodo bezpechnosti tekhnichnoho stanu ta metody kontrolyuvannya [Current Standard of Ukraine
3649: 2010. Wheeled transport vehicles. Requirements in relation to the unconcern of the technical state and methods of controlling]. Kyyiv, Derzhspozhyvstandart Ukrayiny Publ., 2011. 26 p. (In UA)

4. Bulgakov N.A., Gredeskul A.B., Lomaka S.I. Issledovanie dinamiki tormozheniya avtomobilya. Nauchnoe soobschenie no. 18 [Research of dynamics of braking of car. Scientific report №18]. Kharkov, Izd-vo gosuniversiteta im. A.M. Gorkogo Publ., $1962.36 \mathrm{p}$.

5. Lomaka S.I., Aleksa N.N., Getsovich E.M. Avtomatizatsiya protsessa tormozheniya avtomobilya: ucheb. posob. dlya stud. vyissh. ucheb. zaved [Automation of process of braking of car]. Kiev, UMK VO Publ., 1988. 88 p.

6. Guho V.G. Aerodinamika avtomobilya [Aerodynamics of car]. Moscow, Mashinostroenie Publ., 1987. 403 p.

7. Fedosov A.S., Podrigalo M.A. Issledovanie potentsialnyih vozmozhnostey avtomobilya pri deystvii bokovoy silyi $v$ protsesse tormozheniya [Research of potential possibilities of car at the action of lateral force in the process of braking]. Avtomobilnyiy transport. 1980, no. 17, pp. 73-78.

8. Podrigalo M.A., Volkov V.P., Karpenko V.A. Stabilnost ekspluatatsionnyih svoystv kolesnyih mashin [Stability of operating properties of the wheeled machines]. Kharkov, HNADU Publ., 2003. 614 p.

9. Turenko A.N., Klimenko V.I., Ryizhih L.A. Realizatsiya intellektualnyih funktsiy $v$ elektronno-pnevmaticheskom upravlenii transportnih sredstv: monografiya [Realization of intellectual functions is in the pneutronic management of transport vehicles]. Kharkov, HNADU Publ., 2015. $450 \mathrm{p}$.

10. Nazarov V.I. Pereraspredelenie vertikalnyih nagruzok pri ekstrennom tormozhenii legkovogo avtomobilya, dvizhuschegosya $v$ vozdushnom potoke na gorizontalnom uchastke dorogi [Redistribution of the vertical loading at the urgent braking of passenger car locomotive in the current of air on the horizontal area of road]. Vesnik NTU «KhPI», 2014, no.1, pp. 102-110.

11. Fedosov A.S., Podrigalo M.A. Issledovanie potentsialnyih vozmozhnostey avtomobilya pri deystvii bokovoy silyi $v$ protsesse tormozheniya [The research potential of the 
car capacity under the influence of side force during braking]. Avtomobilnyiy transport. 1980, Vol. 17, pp. 73-78.

12. Rusanovskiy A.E. Vliyanie ekspluatatsionnyih faktorov na tormoznuyu dinamiku avtomobilya, oborudovannogo regulyatorami tormoznyih sil. Avtoref. diss. na zdobuttya nauk. stupenya kand. tekhn. nauk: spets. 05.22.20 «Ekspluatatsiya i remont sredstv transporta» [Influence of operational factors on the braking performance of the car equipped with brakepower]. Volgograd, $1982.18 \mathrm{p}$.

13. Podrigalo M.A. Analiz neravnomernosti vertikal'nyh reakcij na kolesah i ee vlijanie na jekspluatacionnye svojstva avtomobilja [Analysis of uneven vertical reactions on the wheels, and its influence on the performance characteristics of the car]. Avtomobilnyiy transport: problemyi i perspektivy Trudy IV mezhdunarod. nauchno-tehn. konf. [Proceedings of the IV-th International Scientific and Technical Conference]. Sevastopol, 2000. pp. 76-79 (In UA).

14. Gredeskul A.B., Podrigalo M.A., Favorov N.Yu. Zakonyi regulirovaniya tormoznyih sil avtomobilya pri deystvii bokovoy silyi $v$ protsesse tormozheniya [Laws regulating braking forces of the car under the influence of side force during braking]. Kharkov, KhADI Publ., 1980. 24 p.

15. Podrigalo M.A., Volkov V.P., Kirchatyiy V.I., Boboshko A.A. Manevrennost $i$ tormoznyie svoystva kolesnyih mashin [Maneuverability and braking characteristics of wheeled machines]. Kharkov, KhNADU Publ., 2003. 403 p.
16. Podrigalo M.A., Nazarov V.I., Nazarov O.I., Nazarov I.O. Pristriy dlya pidvischennya efektivnosti galmuvannya legkovih avtomobiliv [Device for improving braking performance cars]. Patent UA, no. u76189, 2012.

17. Podrigalo M.A., Nazarov V.I., Nazarov O.I., Nazarov I.O. Sposib regulyuvannya galmivnih sil mizh osyami legkovogo avtomobilya [The method of adjusting braking forces between the axles of the car]. Patent UA, no. u75406, 2012.

18. Romanov V.N., Komarov V.V. Teoriya izmereniy. Analiz i obrabotka eksperimentalnyih dannyih: ucheb. posob [Measurement Theory. Analysis and processing of experimental data]. S-Peterburg, SZTU Publ., 2002. 127 p.

19. Nazarov I.A., Nazarov V.I., Nazarov A.I. Povyishenie tormoznyih svoystv legkovyih avtomobiley, oborudovannyih gidravlicheskim tormoznyim privodom, obespechivayuschim bortovoe raspredelenie tormoznoy silyi. [Increase of brake properties of passenger vehicles equipped with a hydraulic brake actuator, providing on-board brake force distribution]. Alternativnyie istochniki energii $v$ transportno-tehnologicheskom komplekse, 2016, Vol. 3, no. 1(4), pp. 342-347. (In Russian)

Рецензент: В.И. Клименко, профессор, д.т.н., ХНАДУ. 